\title{
Effect of Organic Amendments against Macrophomina phaseolina (Tassi) Goid of Brinjal in Pot Culture
}

\author{
A.G. Dapkekar ${ }^{1 *}$, Bholanath Mondal $^{1}$, R.V. Kadam ${ }^{2}$ and A.P. Suryawanshi ${ }^{3}$ \\ ${ }^{1}$ Department of Plant Protection, Palli-Siksha Bhavana (Institute of Agriculture), P.O. \\ Sriniketan, Visva-Bharati, Dist. Birbhum, West Bengal 731 236, India \\ ${ }^{2}$ Department of Plant Pathology, College of Agriculture, Dongershelki Tanda Udgir, \\ (M.S), India \\ ${ }^{3}$ Department of Plant Pathology, Dr.BSKKV, Dapoli (M.S), India
}

*Corresponding author

\begin{abstract}
A B S T R A C T
Keywords

Brinjal, Rakesh, Organic

amendments,

Macrophomina

phaseolina, Pot culture,

Glasshouse etc.

Article Info

Accepted:

04 October 2018

Available Online:

10 November 2018

Present study was undertaken on the stem/root rot caused by Macrophomina phaseolina (Tassi) Goid of Brinjal (Solanum melongena) during 2015-16. A total of 10 amendments were evaluated as pre- sowing application against $M$. phaseolina (sick soil), sowing susceptible brinjal variety Rakesh in pot culture under glass house conditions. The average reduction in mortality (PESR and PESM) recorded with all the test amendments was ranged from 17.11 (FYM) to 66.96 (neem seed cake) per cent over untreated control. However, significantly highest reduction in average mortality $(66.96 \%)$ was recorded with the amendment neem seed cake. This was followed by the amendments viz., cotton seed cake $(61.76 \%)$, groundnut cake $(57.48 \%)$, sunflower cake $(51.90 \%)$, poultry manure $(47.18 \%)$ and castor cake $(46.04 \%)$. Less than 40.00 per cent reduction in average mortality was recorded with vermicompost $(39.22 \%)$ and goat manure (30.69\%); whereas, FYM and compost was found least effective with significantly least reduction $(25.09 \%)$ and $(17.11 \%)$ in average mortality, respectively.
\end{abstract}

\section{Introduction}

Brinjal (Solanum melongena L.), is grown almost throughout India covering an area of 704.96 ha with production of 12994.77 tonnes and productivity of 18.43 tones / ha (NHB, 2012-13). In Maharashtra, area, production and productivity of brinjal were 26 ha, 588 tonnes and 22.62 tones / ha, respectively during 2012-13 (Annonymous, 2013). Brinjal is affected by several pathogens including fungi, bacteria, viruses, nematodes and phytoplasmas. The major diseases of brinjal are: Stem and root rot (Macrophomina phaseolina) Alternaria leaf spot spp. (Alternaria melongena), collar rot (Sclerotium rolfsii), damping off (Pythium spp.), early blight (Alternaria solani), fruit rot (Phytophthora nicotianae), leaf spot (Cercospora melongena), phomopsis blight (Phomopsis vexans), bacterial wilt (Ralstonia solanacearum), mosaic, mottle (viral) and little leaf (phytoplasmal). Macrophomina phaseolina, induce the symptoms: viz. infected 
seedlings shows reddish brown discolouration. hypocotyl is girdled and seedling die due to stem and root rot, water socked lesions appear first and later turn dull light brown, sudden wilting of the plants mainly after the flowering phase, infected plants become weak and dry, the lower stem shows a typical charcoal, grey black discolouration. When the stem is cut open numerous minute black speaks (microsclerotia) are visible on the shredded vascular bundles inside the stem giving the interior part of the stem a charred appearance. The pathogen, Macrophomina phaseolina (Tassi.) Goid is one of the most destructive and wide spread diseases which may cause average losses of 25.60 - $48.62 \%$ (Dinakaran et al., 2005, Jaiman et al., 2009) in many agronomical and horticultural crops. The pathogen being mostly soil borne and polyphagous and hence very difficult to manage with chemicals alone. Therefore, for effective and economical management of the soil borne pathogens like M. phaseolina, by using organic amendments. Therefore, present studies on stem and root rot (M. phaseolina) of brinjal was undertaken.

\section{Materials and Methods}

During the present investigations on charcoal rot caused by Macrophomina phaseolina (Tassi) Goid of Brinjal (Solanum melongena L.), various experiments were conducted at the Department of Plant Pathology, College of Agriculture, Parbhani during 2015-16 to fulfill the objectives defined. The details of the materials used and methods followed for various experiments are described herein the following paragraphs.

\section{Evaluation of organic amendments}

A total of ten organic amendments (as detailed under treatments) will be evaluated against $M$. phaseolina by sick soil method in pot culture under screen house condition.

\section{Experimental details}

Design: CRD

Replications: Three

Treatments: Eleven (pot culture)

\section{Treatment details}

T1: FYM

T2: Compost

T3: Vermicompost

T4: Poultry manure

T5: Gote manure

T6: Groundnut cake

T7: Cotton seed cake

T8: Sunflower cake

T9: Control (untreated)

T10: Neem seed cake

T11: Control (untreated)

Observations in the experiment will be recorded on seed germination and preemergence seed rot will be record at seven days after sowing and that of post- emergence seedling mortality at 30 days after sowing.

The percentage seed germination, preemergence seed rot (PESR) and postemergence seedling mortality (PESM) will be calculated by following formulae.

No. of seeds germinated

Germination $(\%)=$---------------------- X 100

Total no. of seeds sown

No. of seeds ungerminated

PESR $(\%)=$---------------------------- x 100

Total no. of seeds sown

$\operatorname{PESM}(\%)=\frac{\text { No. of seedlings died }}{\text { Total no. of seedlings }}$

C-T

Reduction (\%) in PESR \& PESM = ----- x 100 
Where,

$\mathrm{C}=$ Per cent rot $/$ mortality in treatment pots.

$\mathrm{T}=$ Per cent rot $/$ mortality in untreated control pots.

\section{Results and Discussion}

Effect of organic and inorganic amendments

A total of 10 amendments were evaluated as pre- sowing application against $M$. phaseolina (sick soil), sowing susceptible brinjal variety Rakesh in pot culture under screen house conditions. The results obtained on percentage seed germination, pre-emergence seed rot (PESR), post-emergence seedling mortality (PESM) is presented in the Table 1.

\section{Seed germination}

Result revealed that all the test amendments significantly improved the percentage seed germination over untreated control (sick soil) and it was ranged from 55.55 to 80.00 per cent, as against 48.89 per cent in untreated control (sick soil).

However, neem seed cake was found most effective with significantly highest seed germination of $(80.00 \%)$ and cotton seed cake $(77.78 \%)$, both of which were at par. These were followed by the amendments viz., groundnut cake $(75.55 \%)$, sunflower cake $(71.11 \%)$, poultry manure $(68.89 \%)$, castor cake $(66.67 \%)$, vermicompost $(64.45 \%)$ and goat manure $(60.00 \%)$, all of which were at par. However, compost and FYM were found least effective with comparatively minimum seed germination of 57.78 and 55.55 per cent, respectively. Significant increase in percentage seed germination over control with all the test amendments was recorded and it was ranged from 11.99 (FYM) to 38.89 (neem seed cake) per cent. However, neem seed cake recorded significantly highest increase (38.89 $\%$ ) in seed germination. This was followed by the amendments viz., cotton seed cake (37.14 $\%)$, groundnut cake (35.29\%), sunflower cake $(31.25 \%)$, poultry manure $(29.03 \%)$, castor cake $(26.67 \%)$ and vermicompost $(24.14 \%)$. Less than 20 per cent increase in seed germination was recorded with goat manure $(18.52 \%)$ and compost $(15.39 \%)$.

\section{Pre and post emergence mortalities}

Results (Table 1) revealed that all the test amendments significantly influenced both preemergence seed rot (PESR) and post emergence seedling mortality (PESM), caused by $M$. phaseolina in brinjal variety Rakesh. The pre-emergence seed rot (PESR) recorded with all the test amendment was ranged from 20.00 to 44.45 per cent, as against 51.11 per cent in untreated control (sick soil).

However, significantly least pre- emergence seed rot was recorded with neem seed cake $(20.00 \%)$ and cotton seed cake (22.22\%), both of which were at par. These were followed by the amendments viz., groundnut cake (24.45), sunflower cake (28.89\%), poultry manure $(31.11 \%)$, castor cake $(33.33$ $\%)$, vermicompost $(35.55 \%)$ and goat manure $(40.00 \%)$ all of which were at par. However, compost and FYM were found least effective with comparatively maximum PESR of 42.22 and 44.45 per cent respectively.

Similar trend in respect of the post- emergence seedling mortality (PESM) was also observed and it was ranged from 25.00 to 68.06 per cent, as against 86.31 per cent in untreated control (sick soil). Of the amendments tested, neem seed cake and cotton seed cake were found most effective with significantly least post-emergence seedling mortality, respectively of 25.00 and 28.53 per cent, both of which were at par. 
Table.1 Efficacy of organic and inorganic amendments soil application against M.phaseolina (POT)

\begin{tabular}{|c|c|c|c|c|c|c|c|c|c|}
\hline \multirow[t]{2}{*}{$\begin{array}{l}\text { Tr. } \\
\text { No. }\end{array}$} & \multirow[t]{2}{*}{ Treatments } & \multirow{2}{*}{$\begin{array}{c}\text { Germin } \\
\text { ation } \\
(\%)^{*}\end{array}$} & \multirow{2}{*}{$\begin{array}{l}\% \text { Incr. } \\
\text { in } \\
\text { germinat } \\
\text { ion }\end{array}$} & \multicolumn{2}{|c|}{$\begin{array}{c}\text { Rot/ mortality } \\
(\%)^{*}\end{array}$} & \multirow{2}{*}{$\begin{array}{c}\text { Averag } \\
\text { e } \\
\text { mortali } \\
\text { ty }(\%)\end{array}$} & \multicolumn{2}{|c|}{$\begin{array}{l}\text { Reduction }(\%) \\
\text { over control * }\end{array}$} & \multirow{2}{*}{$\begin{array}{c}\text { Averag } \\
\text { e } \\
\text { reducti } \\
\text { on }(\%)\end{array}$} \\
\hline & & & & PESR & PESM & & PESR & PESM & \\
\hline $\mathrm{T}_{1}$ & Fym & $\begin{array}{c}55.55 \\
(48.18)\end{array}$ & 11.99 & $\begin{array}{c}44.45 \\
(41.79)\end{array}$ & $\begin{array}{c}68.06 \\
(55.64)\end{array}$ & $\begin{array}{c}56.26 \\
(48.58)\end{array}$ & $\begin{array}{c}13.09 \\
(21.19)\end{array}$ & $\begin{array}{c}21.13 \\
(27.08)\end{array}$ & $\begin{array}{c}17.11 \\
(24.32)\end{array}$ \\
\hline $\mathbf{T}_{2}$ & Compost & $\begin{array}{c}57.78 \\
(49.46)\end{array}$ & 15.39 & $\begin{array}{c}42.22 \\
(40.50)\end{array}$ & $\begin{array}{c}57.87 \\
(49.52)\end{array}$ & $\begin{array}{c}50.05 \\
(45.01)\end{array}$ & $\begin{array}{c}17.26 \\
(24.29)\end{array}$ & $\begin{array}{c}32.92 \\
(34.95)\end{array}$ & $\begin{array}{c}25.09 \\
(29.97)\end{array}$ \\
\hline $\mathbf{T}_{\mathbf{3}}$ & $\begin{array}{c}\text { Vermicompos } \\
\mathrm{t}\end{array}$ & $\begin{array}{c}64.45 \\
(53.39)\end{array}$ & 24.14 & $\begin{array}{c}35.55 \\
(36.57)\end{array}$ & $\begin{array}{c}44.81 \\
(42.00)\end{array}$ & $\begin{array}{c}40.19 \\
(39.32)\end{array}$ & $\begin{array}{c}30.36 \\
(33.35)\end{array}$ & $\begin{array}{c}48.07 \\
(43.87)\end{array}$ & $\begin{array}{c}39.22 \\
(38.73)\end{array}$ \\
\hline $\mathbf{T}_{4}$ & $\begin{array}{l}\text { Poultry } \\
\text { manure }\end{array}$ & $\begin{array}{c}68.89 \\
(56.11)\end{array}$ & 29.03 & $\begin{array}{c}31.11 \\
(33.86)\end{array}$ & $\begin{array}{c}38.79 \\
(38.50)\end{array}$ & $\begin{array}{c}34.95 \\
(36.22)\end{array}$ & $\begin{array}{c}39.28 \\
(38.79)\end{array}$ & $\begin{array}{c}55.07 \\
(47.89)\end{array}$ & $\begin{array}{c}47.18 \\
(43.36)\end{array}$ \\
\hline $\mathbf{T}_{\mathbf{5}}$ & Goat manure & $\begin{array}{c}60.00 \\
(50.75)\end{array}$ & 18.52 & $\begin{array}{c}40.00 \\
(39.22)\end{array}$ & $\begin{array}{c}51.85 \\
(46.05)\end{array}$ & $\begin{array}{l}45.93 \\
(42.64)\end{array}$ & $\begin{array}{l}21.43 \\
(27.39)\end{array}$ & $\begin{array}{c}39.94 \\
(39.15)\end{array}$ & $\begin{array}{c}30.69 \\
(33.57)\end{array}$ \\
\hline $\mathrm{T}_{6}$ & $\begin{array}{l}\text { Groundnut } \\
\text { cake }\end{array}$ & $\begin{array}{c}75.55 \\
(60.39)\end{array}$ & 35.29 & $\begin{array}{c}24.45 \\
(29.57)\end{array}$ & $\begin{array}{c}32.32 \\
(34.60)\end{array}$ & $\begin{array}{c}28.39 \\
(32.17)\end{array}$ & $\begin{array}{c}52.38 \\
(46.35)\end{array}$ & $\begin{array}{c}62.58 \\
(52.29)\end{array}$ & $\begin{array}{c}57.48 \\
(49.28)\end{array}$ \\
\hline $\mathbf{T}_{7}$ & $\begin{array}{c}\text { Cotton seed } \\
\text { cake }\end{array}$ & $\begin{array}{c}77.78 \\
(61.90)\end{array}$ & 37.14 & $\begin{array}{c}22.22 \\
(28.06)\end{array}$ & $\begin{array}{c}28.53 \\
(32.24)\end{array}$ & $\begin{array}{c}25.38 \\
(30.22)\end{array}$ & $\begin{array}{c}56.55 \\
(48.76)\end{array}$ & $\begin{array}{c}66.97 \\
(54.93)\end{array}$ & $\begin{array}{c}61.76 \\
(51.80)\end{array}$ \\
\hline $\mathbf{T}_{8}$ & $\begin{array}{c}\text { Sunflower } \\
\text { cake }\end{array}$ & $\begin{array}{c}71.11 \\
(57.49)\end{array}$ & 31.25 & $\begin{array}{c}28.89 \\
(32.47)\end{array}$ & $\begin{array}{c}34.24 \\
(35.78)\end{array}$ & $\begin{array}{c}31.57 \\
(34.17)\end{array}$ & $\begin{array}{c}43.45 \\
(41.20)\end{array}$ & $\begin{array}{c}60.34 \\
(50.96)\end{array}$ & $\begin{array}{c}51.90 \\
(46.07)\end{array}$ \\
\hline$T_{9}$ & Castor cake & $\begin{array}{c}66.67 \\
(54.72)\end{array}$ & 26.67 & $\begin{array}{c}33.33 \\
(35.25)\end{array}$ & $\begin{array}{c}36.67 \\
(37.21)\end{array}$ & $\begin{array}{c}35.00 \\
(36.25)\end{array}$ & $\begin{array}{c}34.53 \\
(35.93)\end{array}$ & $\begin{array}{c}57.54 \\
(49.35)\end{array}$ & $\begin{array}{c}46.04 \\
(42.70)\end{array}$ \\
\hline $\mathbf{T}_{10}$ & $\begin{array}{c}\text { Neem seed } \\
\text { cake }\end{array}$ & $\begin{array}{c}80.00 \\
(63.41)\end{array}$ & 38.89 & $\begin{array}{c}20.00 \\
(26.55)\end{array}$ & $\begin{array}{c}25.00 \\
(29.99)\end{array}$ & $\begin{array}{c}22.50 \\
(28.31)\end{array}$ & $\begin{array}{c}60.88 \\
(51.27)\end{array}$ & $\begin{array}{c}73.03 \\
(58.69)\end{array}$ & $\begin{array}{c}66.96 \\
(54.90)\end{array}$ \\
\hline $\mathbf{T}_{11}$ & $\begin{array}{c}\text { Control } \\
\text { (untreated) }\end{array}$ & $\begin{array}{c}48.89 \\
(44.35)\end{array}$ & 00.00 & $\begin{array}{c}51.11 \\
(45.62)\end{array}$ & $\begin{array}{c}86.31 \\
(68.26)\end{array}$ & $\begin{array}{c}68.71 \\
(55.97)\end{array}$ & $\begin{array}{c}00.00 \\
(00.00)\end{array}$ & $\begin{array}{c}00.00 \\
(00.00)\end{array}$ & $\begin{array}{c}00.00 \\
(00.00)\end{array}$ \\
\hline & $\mathrm{SE} \pm$ & 1.90 & -- & 1.90 & 2.55 & 1.60 & 2.85 & 2.92 & 2.51 \\
\hline & $\mathrm{CD}(\mathrm{P}=\mathbf{0 . 0 5})$ & 5.59 & -- & 5.59 & 7.54 & 4.71 & 8.43 & 8.63 & 6.64 \\
\hline
\end{tabular}

*-Mean of three replications, Figures in parenthesis are arc sine transformed values

PESR- Pre emergence seed rot, PESM- Post emergence seedling mortality whereas, FYM was least effective with last $(11.99 \%)$ increase in seed germination.

These were followed by the amendments viz., groundnut cake $(32.32 \%)$, sunflower cake (34.24\%), castor cake (36.67\%), poultry manure $(38.79 \%)$ and vermicompost (44.81 $\%)$, all of which were at par.

More than 50 per cent PESM was recorded with the amendments viz., goat manure, compost and FYM (51.85\%), (57.87 \%) and FYM (68.06 \%) respectively. The average mortality recorded with all the test amendments was ranged from 22.50 to 56.26 per cent, as against 68.71 per cent in untreated control (sick soil). However, significantly least average mortality was recorded with neem seed cake $(22.50 \%)$, followed by the amendments viz., cotton seed cake $(25.38 \%)$, groundnut cake (28.39\%), sunflower cake $(31.57 \%)$, poultry manure $(34.95 \%)$, castor cake $(35.00 \%)$, vermicompost $(40.19 \%)$ and goat manure $(45.93 \%)$. Whereas, compost and FYM were found least effective with 
comparatively maximum average mortality of 50.05 and 56.26 per cent, respectively.

\section{Reduction in mortality}

All the test amendments were found to reduce / control both the mortalities (pre- and post) over untreated control (Table 1). The percentage reduction / control of the pre- and post- emergence mortalities were ranged from 13.09 (FYM) to 60.88 (neem seed cake) per cent and 21.13 (FYM) to 73.03 (neem seed cake) per cent, respectively. Of the amendment tested significantly highest reduction in pre- emergence seed rot $(60.88$ $\%)$ and post- emergence seedling mortality $(73.03 \%)$ were recorded with neem seed cake.

These were followed by the amendments viz., cotton seed cake (56.55 and $66.97 \%)$, groundnut cake (52.38 and $62.58 \%)$ and sunflower cake (43.45 and $60.34 \%)$. Less than 50.00 per cent reduction in both the mortalities were recorded with poultry manure (39.28 and $55.07 \%$ ), followed by castor cake (34.53 and $57.54 \%)$, vermicompost (30.36 and $48.07 \%$ ) and goat manure (21.43 and $39.94 \%$ ) and compost (17.26 and $32.92 \%)$. The soil amendment with FYM was found least effective with significantly least reduction in PESR (13.09 $\%)$ and PESM (21.13\%).

The average reduction in mortality (PESR and PESM) recorded with all the test amendments was ranged from 17.11 (FYM) to 66.96 (neem seed cake) per cent over untreated control. However, significantly highest reduction in average mortality $(66.96 \%)$ was recorded with the amendment neem seed cake. This was followed by the amendments viz., cotton seed cake $(61.76 \%)$, groundnut cake $(57.48$ $\%)$, sunflower cake (51.90\%), poultry manure $(47.18 \%)$ and castor cake (46.04 \%). Less than 40.00 per cent reduction in average mortality was recorded with vermicompost (39.22 \%) and goat manure (30.69 \%); whereas, FYM and compost was found least effective with significantly least reduction $(25.09 \%)$ and $(17.11 \%)$ in average mortality, respectively.

Similar study was done by Waghe, Langewar (1981) on Sesamum and Singh et al., (1990) studied the effect of soil amendment with inorganic and organic sources of nitrogen on the incidence of root rot $(M$. phaseolina) of sesamum. Haque et al., (1998) reported that the soil application of Neem seed cake and cotton seed cake (each@ 20 and 100 g /1 m row) were effective against root rot casting pathogens (M. phaseolina, $R$. solani and $F$. oxysporum) alone and in combination with $P$. aeruginosa. Jaiman et al., (2009) evaluated soil amendments against $M$. phaseolina, casing root rot of cluster bean.

This study conclude that the all tested soil amendments significantly improved the percentage seed and significantly influenced both pre-emergence seed rot (PESR) and post emergence seedling mortality (PESM), caused by $M$. phaseolina in brinjal variety Rakesh. The average reduction in mortality (PESR and PESM) recorded with all the test amendments was ranged from 17.11 (FYM) to 66.96 (neem seed cake) per cent over untreated control. However, significantly highest reduction in average mortality (66.96\%) was recorded with the amendment neem seed cake.

\section{References}

Anonymous (2013). Directorate of Economic and Statistics, Department of Agril. and Cooperation.

Dinkaran, D., Sachithanantham, K. and Nainamohammed, S. E. (2005). Screening of sesame genotypes against root rot pathogen, Macrophomina 
phaseolina (Tassi.) Goid. Indian J. PI.Path. 23 (1\&2):66-68.

Haque, S. E., Zaki, M. J., Vahidy, A. A. and Ghaffar A. (1998). Effect of organic amendments on the efficiency of Pseudomonas aeruginosa in the control of root rot disease of safflower. Pakistan. J. Bot. 30 (1): 45-50.

Jaiman, R. K., Jain, S. C. and Sharma, P. (2009). Field evaluation of fungicides, bioagents and soil amendments against root rot caused by Macrophomina phaseolina in cluster bean. J. Mycol. PI. Pathol. 39 (1): 74-76.

Singh, A., Bhowmik, T. P. and Chaudhary, B. S. (1990). Effect of soil amendment with inorganic and organic sources of nitrogenous manures on the incidence of root rot and seed yield in sesamum. Indian Phytopath. 43: 442-443.

Waghe, S. V. and Lanjewar, R. D. (1981). Effect of different oilcakes amendments on seedling survival against wilt, root and stem rot diseases of Sesamum. Oilseed J. 12: 69-73.

\section{How to cite this article:}

Dapkekar, A.G., Bholanath Mondal, R.V. Kadam and Suryawanshi, A.P. 2018. Effect of Organic Amendments against Macrophomina phaseolina (Tassi) Goid of Brinjal in Pot Culture. Int.J.Curr.Microbiol.App.Sci. 7(11): 95-100. doi: https://doi.org/10.20546/ijcmas.2018.711.014 